\title{
Effect of row spacing on growth and yield of Sesame (Sesamum indicum 1.) in Yola, Adamawa State, Nigeria
}

\author{
Jakusko, B.B.*, Usman, B.D. and Mustapha A.B. \\ *Department of Agronomy, Taraba State University, Jalingo, Nigeria \\ Department of Crop Production and Horticulture, Modibbo Adama University of Technology, Yola, \\ Adamawa State, Nigeria
}

\begin{abstract}
Sesame or Beniseed (Sesamum indicum L.) is cultivated in almost all the tropical and subtropical countries of Asia and Africa. However, low yield is obtained as results of poor cultural practices among others discourage growers. Field experiments were carried out to investigate the effects of row spacing on the growth and yield of Sesame (Sesamum indicum L.). The field trials were conducted in 2009 and 2010 rainy seasons at the Teaching and Research Farm of the Department of Crop Production and Horticulture, Modibbo Adama University of Technology, Yola. The treatments consisted of three row spacing $(60 \times 15 \mathrm{~cm}, 60 \times 10 \mathrm{~cm}$ and $75 x$ $10 \mathrm{~cm}$ ) which was laid out in a split plot design replicated three times with plot size $3 \mathrm{~m} \times 2 \mathrm{~m}$. Parameters measured include length of capsule, number of capsule per plant, seed yield per plot, 1000 -seed weight among others. Data collected were subjected to analysis of variance and the means were separated using least significant difference (LSD). The result revealed that there were significant effect of spacing on the number of seed per capsule, capsule per plant and length of capsule as well as 1000 seed weight and yield per hectare in both seasons. From the findings of this study, it is suggested that $75 \times 10 \mathrm{~cm}$ spacing should be adopted in Yola.
\end{abstract}

Key words: Row spacing, seed yield, sesame, yield components.

\section{Introduction}

Sesame or Beniseed (Sesamum indicum L.) is cultivated in almost all tropical and sub tropical Asian and African countries for its highly nutritious and edible seeds ${ }^{\{1\}}$. In Nigeria it is cultivated in the dried, Northern and Southern Guinea, Sudan and Sahel Savannah zone ${ }^{\{2\}}$.

The low yields coupled with problems encountered during harvesting sesame have tended to discourage growers, leading to a decline in the total area devoted to its cultivation. Plant spacing determines the canopy structure which affect the crop in two important ways: first through light interception and distribution'; secondly, through correlated physiological development and morphological changes ${ }^{\{3\}}$. Plant spacing varies from one plant species to another and thus must strictly be controlled to prevent over-crowding which may in turn affect growth and development of yield of cultivated crops ${ }^{\{4\}} \cdot{ }^{\{5\}}$ observed that adequate spacing of crop is important for good yield. Widely spaced crops $(35 \mathrm{~cm})$ produced shorter plants as a result of reduce competition for growth factors. Harper (1983) reported with non -tillering (branching) crop varieties, higher yield could be obtained by closer spacing even though result in lower yield per plant will give high total yield per hectare once the optimum population is not exceeded. Other authors, reported that decrease in inter-row spacing resulted in decreased yield per plant although yield per hectare increase significantly ${ }^{\{6\}}{ }^{[7\}}$.

Efforts to improved sesame yield become pertinent to meet demand; since sesame is gaining significance in Nigeria Agriculture because of its importance as a cash crop in the world market. Nigeria current annual export is valued at about 20 million USD and the country is the primary supplier of Sesame seed to the world's largest importer, Japan ${ }^{\{8\}}$.

The major sesame producing areas in Nigeria are Nassarawa, Jigawa, Jigawa, Yobe, Kano, Katsina, Kogi, Gombe and Benue State. Even though, Adamawa state (where Yola is the state capital) is not among the major producing states, its production is rapidly gaining ground. However, there is limited knowledge on adequate spacing of the crop in the study area. Hence, this research was conducted to investigate the effect of row spacing on the growth and yield of sesame in Yola, Adamawa state, Nigeria.

\section{Materials And Methods}

Field experiments were carried out at the Teaching and Research Farm of the Modibbo Adama University of Technology, Yola (Latitude $9^{0} 10^{\prime} \mathrm{N}$ and longitude $11^{0} 14^{\prime} \mathrm{E}$ and 158,5 above sea level), during the 2009 and 2010 cropping seasons, to study the effect of spacing on the growth and yields of sesame. Composite soil sample were collected during the two cropping seasons to determine physicochemical properties of the soil on the experimental site. Rainfall data was also collected.

The treatments consisted of three row spacing of $(60 \times 15 \mathrm{~cm}, 60 \times 10 \mathrm{~cm}$ and $75 \times 10 \mathrm{~cm})$. The treatments were laid out in a split plot design and replicated three times using plot size of $3 \mathrm{~m} \times 2 \mathrm{~m}$. Sesame 
Effect of row spacing on growth and yield of Sesame (Sesamum indicum l.) in Yola, Adamawa State,

variety pb-Til No. 1 obtained from Adamawa State Agricultural Development Programme (ADADP) was used for the studies. The field was ploughed and harrowed during the both seasons to obtain a fine tilt, thereafter marked into plots. The seed were sowed on July 24, 2009 and July 29, 2010 for the first and second year experiments respectively. Seeds were sown in drills and recommended dose of NPK was applied according to Agronomic recommendation by ADADP (1996). Data collected include number of capsule per plants, length of capsule, number of seed per capsule, yield per plot $(\mathrm{g})$, seed yield per hectare $(\mathrm{kg} / \mathrm{ha}-1)$ and 1000 seed weight. The data were then subjected to analysis of variance (ANOVA) and mean separated least significant difference (LSD) ${ }^{\{9\}}$.

\section{Results And Discussion}

The soil physicochemical parameters before planting and the rainfall data are shown in table 1 . Table 2 contained data on the effect of spacing on some growth parameters of Sesamun indicum (L).

Table 1:Some physicochemical properties and monthly rainfall of the experimental site during the 2009 and 2010 cropping season

\begin{tabular}{|c|c|c|}
\hline Soil properties & 2009 & 2010 \\
\hline Soil pH $\left(\mathrm{H}_{2} \mathrm{O}\right)$ & 6.5 & 6.4 \\
\hline Organic carbon $\left(\mathrm{g} \mathrm{kg}^{-1}\right)$ & 1.4 & 1.1 \\
\hline Total N $\left(\mathrm{g} \mathrm{kg}^{-1}\right)$ & 0.04 & 0.04 \\
\hline Available P ( $\left.\mathrm{mg} \mathrm{Kg}^{-1}\right)$ & 0.09 & 0.09 \\
\hline C.E.C (cmol $\left.\mathrm{kg}^{-1}\right)$ & & 0.21 \\
\hline Exchangeable $\mathrm{K}\left(\mathrm{cmol} \mathrm{kg}^{-1}\right)$ & 0.3 & 0.54 \\
\hline Exchangeable $\mathrm{Na}\left(\mathrm{coml} \mathrm{kg}{ }^{-1}\right)$ & 0.09 & 0.08 \\
\hline Exchangeable $\mathrm{Ca}\left(\mathrm{coml} \mathrm{kg} \mathrm{kg}^{-1}\right)$ & 2.54 & 2.65 \\
\hline Exchangeable $\mathrm{Mg}$ (coml. $\mathrm{kg}^{-1}$ ) & 1.25 & 1.45 \\
\hline Textural class & Sandy loam & Sandy loam \\
\hline \multicolumn{3}{|l|}{ Monthly rainfall (mm) } \\
\hline March & 0.00 & 1.6 \\
\hline April & 69.8 & 4.0 \\
\hline May & 18.95 & 48.5 \\
\hline June & 31.8 & 157.9 \\
\hline July & 80.4 & 88.0 \\
\hline August & 161.7 & 151.0 \\
\hline September & 176.6 & 116.0 \\
\hline October & 38.2 & 77.1 \\
\hline Total & 577.45 & 644.10 \\
\hline Mean & 82.49 & 86.51 \\
\hline
\end{tabular}

Spacing had no significant effect on primary branches in 2009 but significant effect was observed with $60 \times 15 \mathrm{~cm}$ on primary branches per plant in 2010 . The highest value of 2.60 was recorded. The number of primary branches combined analysis was not significant at $(\mathrm{p} \leq 0.05)$ effect of spacing. While the effect of $75 \mathrm{x}$ $10 \mathrm{~cm}$ spacing on number of secondary branches was only significant in 2009 producing the highest value of 1.50. The combined analysis however showed no significant with the spacing.

The significant effect of spacing on primary and secondary branches were in line with the findings of ${ }^{\{10\}}$ and that of ${ }^{\{11\}}$ who reported that plant population could reduce the number of primary and secondary branches per plant in the study of groundnut. Similarly, ${ }^{\{12\}}{ }^{13\}}$ and Indian Council on Agricultural Research ${ }^{\{14\}}$ corroborated these findings. However, ${ }^{\{15\}}$ observed no significant response on number of primary branches in the inter-row spacing of sesame.

Table 2: Effect of spacing on No of leaves 9 WAS, No. of primary branches/plant and No. of secondary branches/plant in 2009 and 2010 rainy seasons in Yola

\begin{tabular}{|c|c|c|c|c|c|c|c|c|c|}
\hline \multirow[t]{2}{*}{ Treatment } & \multicolumn{3}{|c|}{ No of leaves 9 WAS } & \multicolumn{3}{|c|}{ No. of primary branches/plant } & \multicolumn{3}{|c|}{ Plant height at maturity } \\
\hline & 2009 & 2010 & combined & 2009 & 2010 & combined & 2009 & 201 & combined \\
\hline \multicolumn{10}{|c|}{ Spacings (cm) } \\
\hline $60 \times 15$ & 20.11 & 17.00 & 18.56 & 3.37 & 2.60 & 2.99 & 1.40 & 1.28 & 1.34 \\
\hline $60 \times 10$ & 18.44 & 15.22 & 16.83 & 3.38 & 2.43 & 2.97 & 1.22 & 1.39 & 1.31 \\
\hline $75 \times 10$ & 17.22 & 14.33 & 15.78 & 3.51 & 2.20 & 2.79 & 1.50 & 1.42 & 1.46 \\
\hline LSD & 3.62 & 8.08 & 6.33 & 0.33 & 0.27 & 0.49 & 0.10 & 0.16 & 0.02 \\
\hline Interaction & $\mathrm{Ns}$ & $\mathrm{Ns}$ & $*$ & $\mathrm{Ns}$ & * & $\mathrm{Ns}$ & * & $\mathrm{Ns}$ & * \\
\hline
\end{tabular}


Row spacing had significant effect on days to $50 \%$ flowering which do not corroborated the finding of ${ }^{\{16\}}$ that plant population density had no significant effect on flowering on soyabean in a research conducted at Samaru -Zaria. The significant increase in number of seed per capsule when spaced wider $(75 \mathrm{x} 10 \mathrm{~cm})$ agrees with the findings of ${ }^{\{17\}}$ who also reported that wider spacing produce more healthy plant than close spaced plants. However, the non-significant influence of spacing in the combined analysis on number of seed per capsule confirms the report of ${ }^{\{18\}}$ who started that maximum yield was obtained in close spacing of crops. The increase in the number of capsule agree with the findings of ${ }^{\{19\}}$ who reported that environment and length of growth period have significant effect on number of capsule in sesame.

1000 -seed weight was found to be higher with wider spacing in this study. ${ }^{20\}}$ reported that as plant population increased, the seed size decreases. That is really expected because the number of capsule per plant and seed yield per plant, had significant positive phenotypic and genotypic correlation with 1000-seed weight and yield per hectare, indicating that the seed yield per plant was also positively and significantly correlated with 1000-seed weight and yield per hectare.

The significant interaction of spacing showed on growth and yield character for two combined data was also observed by ${ }^{\{21\}}$ who reported that, the spacing between stand determines the number of stand per hectare and the number of plant per stand together determine the plant population density. The significant effect of combine analysis of spacing on number of capsule per plant and length of capsule agree with the findings of ${ }^{\{22\}}$ who reported that length of capsule and number of capsule per plant were found higher in plant when grown in wider spacing than those at close spacing.

The number of seed per capsule was significantly affected by spacing in 2009 rainy season (table 3 ). The highest number of seed (64.14) was recorded with the combine analysis, however, showed that the number of seeds per capsule increases significantly as spacing increases (table 3 ).

Length of capsule was significantly affected only in 2010 rainy season (table 4). The capsules were significantly large with the value of $2.9 \mathrm{~cm}$ on $60 \times 10 \mathrm{~cm}$ than when spaced $75 \times 10 \mathrm{~cm}$ producing the length of $2.57 \mathrm{~cm}$. While the combined analysis showed significant effect also when $60 \mathrm{x} 10 \mathrm{~cm}$ spacing as it gives the value of $2.58 \mathrm{~cm}$ (table 3 ).

A 1000-seed weight was highly significantly affected by spacing (table 3). There was significant difference between the spacing and the highest weight value of $3.28 \mathrm{~g}$, recorded on $75 \times 10 \mathrm{~cm}$ (table 4).

The effect of spacing on seed yield $\left(\mathrm{kgha}^{-1}\right)$ was significant in 2010 (table 4). The significant effect recorded the highest value of 561.63 with $60 \times 15 \mathrm{~cm}$. The combine analysis however, showed no significant effect on seed yield $\left(\mathrm{kgha}^{-1}\right)$ (table 4$)$.

Some growth character and yield components in the study were significantly influence by the interaction effect of spacing. There was an interaction effect of spacing on number of leaves at 9WAS, secondary branches per plant and number of days to $50 \%$ flowering as growth characters. While significant effect was observed on number of capsule per plant, number of seed per capsule, length of capsule, 1000-seed weight and seed yield $\mathrm{kgha}^{-1}$.

Table 3: Effect of spacing on Days to 50\% Flowering, Number of Capsule/plant, and number of seeds/capsule in 2009 and 2010 rainy seasons in Yola

\begin{tabular}{|c|c|c|c|c|c|c|c|c|c|}
\hline \multirow[t]{2}{*}{ Treatment } & \multicolumn{3}{|c|}{ Day to $50 \%$ Flowering } & \multicolumn{3}{|c|}{ Number of Capsules/Plant } & \multicolumn{3}{|c|}{ Number of Seeds/capsule } \\
\hline & 2009 & 2010 & Combined & 2009 & 2010 & Combined & 2009 & 2010 & Combined \\
\hline$\overline{\text { Spacing }(\mathrm{cm})}$ & & & & & & & & & \\
\hline $60 \times 15$ & 42.78 & 43.11 & 42.92 & 117.22 & 142.89 & 130.06 & 61.67 & 63.00 & 62.33 \\
\hline $60 \times 10$ & 42.33 & 42.89 & 42.61 & 107.44 & 108.63 & 82.4 & 60.89 & 62.22 & 61.56 \\
\hline $75 \times 10$ & 41.78 & 42.33 & 42.06 & 80.67 & 70.44 & 94.67 & 64.44 & 66.00 & 65.22 \\
\hline LSD & 0.79 & 1.14 & 1.61 & 21.44 & 46.18 & 59.18 & 1.82 & 3.41 & 4.48 \\
\hline Interaction & $*$ & $\mathrm{Ns}$ & * & $\mathrm{Ns}$ & $\mathrm{Ns}$ & * & $*$ & $\mathrm{Ns}$ & $*$ \\
\hline
\end{tabular}

Table 4: Effect of spacing on number of capsules, length of capsule and 1000-seed weight, and Seed Yield/kg $\mathrm{ha}^{-1}$ in 2009 and 2010 rainy seasons in Yola

\begin{tabular}{|c|c|c|c|c|c|c|c|c|c|}
\hline \multirow[t]{2}{*}{ Treatment } & \multicolumn{3}{|c|}{ Length of capsule } & \multicolumn{3}{|c|}{ 1000-seed weight } & \multicolumn{3}{|c|}{ Seed Yield/kg ha ${ }^{-1}$} \\
\hline & 2009 & 2010 & Combined & 2009 & 2010 & Combined & 2009 & 2010 & Combined \\
\hline \multicolumn{10}{|c|}{ Spacings $(\mathrm{cm})$} \\
\hline $60 \times 15$ & 2.74 & 2.77 & 2.77 & 2.24 & 2.64 & 2.44 & 598.13 & 561.13 & 579.6 \\
\hline $60 \times 10$ & 2.69 & 2.87 & 2.78 & 2.03 & 2.60 & 2.31 & 758.30 & 383.83 & 398.34 \\
\hline $75 \times 10$ & 2.57 & 2.53 & 2.56 & 3.28 & 2.60 & 2.44 & 500.00 & 480.23 & 490.1 \\
\hline LSD & 0.08 & 0.18 & 0.36 & 0.09 & 0.10 & 0.31 & 396.48 & 142.88 & 459.9 \\
\hline Interaction & * & Ns & * & Ns & $* *$ & * & Ns & * & Ns \\
\hline
\end{tabular}




\section{Conclusion}

In conclusion, the result of this study indicated that yield and yield components - numbers of seed per capsule, number of capsule per plant, length of capsule and 1000-seed weight were significantly influenced by row spacing. Significantly higher yield was recorded with row spacing of $75 \times 10 \mathrm{~cm}$ in both 2009 and 2010 cropping seasons and hence suggest for adoption in the study area.

\section{Acknowledgement}

The authors wish to thank Mr Ahmed Musa Iliyasu for his invaluable assistance for secretarial work.

\section{References}

[1] Iwo, G.A. Idowu, A.A. \& A.A. Ochigbo (2002). Evaluation of sesame genotypes for yield stabilityand selection in Nigeria. Nigeria Agricultural Journal 33:76-82.

[2] Alegbejo, M.D., Iwo, G.A., Abo, M.E. \& A.A. Idowu (2003). Sesame: a potential industrial and export oil seed crop in Nigeria. Journal of Sustainable Agriculture 23(1):59-76.

[3] Evans, R.C, \& B.T. Kang (1978). The quantitative analysis of plant growth.Blackwell's Scientific Publication, London pp135-137.

[4] Sajo, A.A. Okunsanya, B.A.O. Jada, A.Y., and D. Bello (2002). Effect of plant spacing on the growth and yield of cowpea in Yola, Nigeria. Proceedings of the $34^{\text {th }}$ Annual Conference of the Agricultural Society of Nigeria, held at Abubakar Tafawa Balewa University, Bauchi, October, 15 $5^{\text {th }}-19,2002$.

[5] Youdeowei, A. (1986). Introduction to Tropical Agriculture. Anthony, Y., F.O.C. Ezedinma and C.O Ochapa (eds) Longman Limited, London.

[6] Olowe, V.I.O \& L.D. Busari (1994). Appropriate plant population and spacing of sesame (Sesamum indicum L.) in the SGS of Nigeria. Tropical Oils Seed Journal 2:18-27.

[7] Adeyemo, M.O., Ojo, A.A. \& D.T. Gungula (1992). Effect of plant population density on agronomic traits and seed yield of sesame (Sesamum indicum L.) in the southern guinea savannah environment. Tropical Oilseed Journal 1992, 135145.

[8] Anonymous (1996). Crop Production Recommendations for Adamawa State, ADADP, Yola, Nigeria.

[9] Gomez, K.A. Gomez, A.A. (1984). Statistical Procedures for Agricultural Research,2 ${ }^{\text {nd }}$ Edition, John Willey and Sons, New York, $680 \mathrm{p}$.

[10] Anonymous (2002). Overview of the Nigeria Sesame industry. Prepared for the United StatesAgencyforInternational Development (USAID)/Nigeria. Chemonic International Inc., Washington DC, USA pp34.

[11] Sardauna, V. \&S.S. Kandhola (2007). Productivity of semi-spreading and bunch type varieties of groundnut as influenced by sowing data. An open access Journal Published by ICRISAT5(1):1-3. SAT eJournal.icriat.org. accessed 29/2/2011.

[12] Reddy, S.R. (2004). Principles of Crop Production. Kelyani Publishers, New Delhi, India 649p.

[13] Indian Council on Agricultural Research (ICAR, 2006). Sesame: In: Handbook of Agriculture: Facts and Figures for Farmers, Students and all interested in farming. Awa, T.K \& P. Sibhir (eds) Directorate of Information \& Publication of Agriculture pp972978.

[14] Adeyemo, M.O., Ojo, A.A. \& D.T. Gungula (1992). Effect of plant population density on agronomic traits and seed yield of sesame (Sesamum indicum L.) in the southern guinea savannah environment. Tropical Oilseed Journal 1992, 135145.

[15] Chiezey, U.E. (2001). Capsule abortion and grain yield in soyabean as influence byphosphorus nutrition and plant density at Samaru Nigeria. The Plant Scientist 2(1\&2):121-133.

[16] Husain, M.D., Rahman, M.A., Haqu, M.M. Islam, M.S. \& M.A. Salam (1989). Year round okra production and economic return as influence by spacing in Barisal region. Bangla Journal of Agricultural Resoruces 26:319-328.

[17] Gorachand, M.SC. \& G. Modal (1990). Growth yield of okra (Abelmoschus esculentus L. Moench) as influence by time of sowing and planting density. Orissa Journal of Horticulture 18:26-31.

[18] Kafiriti, E.M., \& J. Deckers (2001). Sesame, in Crop Production in Tropical Africa. DGIC; Ministry of Foreign Affairs, External Trade \& International Cooperation's, Brussels, Belgium, Raw Mackers, R.H. (ed) p797-803.

[19] Kadams, A.M. \& A.A. Sajo (1988). Variability and Correlation Studies in yield and yield components in bambara nut (Vigna subterrenea (L.) Verdec). Journal of Applied Science and Management 2:66-70.

[20] Onwueme, I.C. \& T.D. Sinha (1991). Field Crop Production in Tropical Africa: Principles and Practice. Technical Centre for Agriculture and Rural Cooperation. Netherlands 488p.

[21] Christo, E.I. \& M.O. Onuh (2005). Influence of plant spacing on the growth and yield of Okra (Abelmoschus esculentus L. Moench) Proceedings of the $39^{\text {th }}$ Conference of the Agricultural Society of Nigeria, Benin, pp 51-53. 